\title{
Kriz Yönetimi ve Hermeneutik ${ }^{*}$
}

\author{
Crisis Management and Hermeneutics
}

Öğr. Gör. Erkam TEMIR ${ }^{1}$

\begin{abstract}
Özet
Kriz yönetimi dahilinde yapılan bazı basın açıklamalarının, basın toplantılarının, sosyal medya üzerinden yapılan açıklamaların vb. krizi avantaja çevirmenin aksine kriz sürecini uzattığı ve etkisini arttırdığını gözlemlemek mümkündür. Makalenin ana konusu kriz yönetimi sürecinin iyi planlanamamasının ve iyi yürütülememesinin temelinde yatan büyük gerçekliklerden birinin yanlış kurgulanmış iletişim stratejileri olduğu ve bununla birlikte ortaya çıkan entropinin ve yanlış algının nedeninin hermeneutik problemler olduğu varsayımıdır. Anlatılmak istenen "gerçek" ve verilmek istenen mesajla birlikte, algılanan gerçek ve alınan mesaj arasındaki temel farklılık; kolektif paradigmanın ve algının dönüşmesinde, krizin büyümesinde ve yaygınlaşarak yapısallaşmasındaki en temel etki ve dinamik olarak karşımıza çıkmaktadır. Henüz kriz başlangıç sürecinde iken yapılan basın açıklamaları, basın toplantıları vb. uygulamalarda yanlış kurgulanan cümleler, objeler vb. unsurlar temel hermeneutik problemlerin doğmasına ve algının yönetilememesine neden olmakta ve krizi önü alınamayan bir süreç haline dönüştürmektedir. Sonuç olarak hermeneutik algı, birçok krizin temelinde bulunan, arzu edilmeyen bir şekilde anlamlandırmaya bağlı olarak gelişip büyüyen krizin yarattığı etkinin temel sebeplerinden birisi ve en önemlisi olarak açılanabilir. Bu nedenle ilk bölümde hermeneutik kavramı üzerinde durulmuş ve ikinci bölümde hermeneutik ve kriz yönetimi olgusu yaşanmış örnekler ile değerlendirilmiştir.
\end{abstract}

Anahtar kelimeler: Halkla ilişkiler, kriz yönetimi, hermeneutik, algı, yorum

\begin{abstract}
It is possible to observe crisis periods during which public statements, press conferences and statements that are made on the social media make the crises period longer and increase its effects instead of turning it into an opportunity throughout the management of the crisis. The main idea of the article is the assumption that one of the biggest realities as an underlying reason of not planning and conducting the crisis management in a better way is the wrongly fictionalized communication strategy and the reason behind the entropy and misperception coming as a result of it is the hermeneutic problems. The main difference between what is presented and what is perceived as reality and a message seems to be the basic effect and a dynamic that plays a role on the transformation of the collective paradigm, growing of the crisis and becoming a more common and structuralized concept. Sentences or objects that are wrongly made in the public statements and press conferences at the very beginning of the crisis management period cause hermeneutic problems and prevent the perception leading so that it transforms the crisis into an inevitable process. Hermeneutic perception can be explained as the most important and basic reason of the effects that the crisis creates which can be found on the basis of many crises and undesirably grows based on the meaning attached. For this reason; in the first section it is focused on hermeneutic and in the second section both hermeneutic and crisis management are evaluated by real life examples.
\end{abstract}

Key words: Public relations, crisis management, hermeneutics, perception, review

\footnotetext{
* Bu makale, yazarın "Kriz Yönetimi ve Hermeneutik" isimli yüksek lisans tezinden üretilmiştir.

${ }^{1}$ Erciyes Üniversitesi, İletişim Fakültesi, Halkla İlişkiler ve Tanıtım Bölümü, erkamtemir@erciyes.edu.tr, Orcid ID: 0000-0002-4387-2728)
} 


\section{Giriş}

Kriz yönetiminde sosyoloji, psikoloji, ekonomi hatta antropolojinin sunduğu olanakları kriz yönetimine entegre ederek "neo-proaktif" yöntemler inşa etmeye çalışmak, bu yöntemlerin yaşam gerçekliği ile uyumunu denetlemek bir gereklilik olarak görülmektedir. Sunulan mesajların arzu edilmeyen bir biçimde algılanışı ve bu algı üzerinden işlenmeye başlanılması kuruluşların veya mesaj sunanların korkulu rüyası olmaktadır. Sunulan mesajların hedef kitleler tarafından nasıl algılanabileceği ayrı bir çalışma alanı olmalıdır.

Arzu edilmeyen biçimde anlaşılabilecek ve yorumsanabilecek mesajların yorumsaması kurumun rakipleri, basın mensupları, sivil toplum örgütleri, siyasiler, hedef kitle ve/veya diğer şahıslar tarafindan yapılabilmektedir. Arzu edilmeyen yorumsama gayri ihtiyari olabileceği gibi bilinçli de yapılmış olabilir. Gayri ihtiyari yorumsama kolektif şuurdan kaynaklanabilmektedir. Kurum mesajını iletenlerin mesajın alıcılarının anlamlandırma sürecini bilmemeleri veya önemsememeleri böyle bir durum meydana getirebilmektedir. Bununla birlikte kurumun krizle karşı karşıya kalması, hatta yok olmasından çıkar elde edebilecek rakip kuruluşlar, siyasiler, kurumun bir eylemine veya tüm varlığına karşı çıkan sivil toplum örgütleri ve/veya basın kuruluşları bilinçli bir şekilde arzu edilmeyen yorumsama yoluna gidebilmektedirler.

Gelişen ve teknolojiye bağımlı organizasyonlar dünyasında, kurumlar an be an hedef kitleleriyle karşılıklı iletişim ve etkileşim halindedirler. Bu yakınlık ve karşılıklı etkileşimi sağlayan olanaklar nedeniyle kurumlar sıklıkla hermeneutik problemler ile yüz yüze gelebilmektedirler.

Kurum ve hedef kitle ya da kamu ve kurum arasında iletişim eksikliğinin giderilmesi amaçlanırken, algının yönetilmesi temel amaçtır. Bu açıdan hermeneutik problemlerin giderilmesi, yanlış algıya dayalı açmazların oluşmasındaki temel problemlerin (hermeneutik problemlerin) tespit edilmesi ve kaçınılması gerekmektedir.

$\mathrm{Bu}$ çalışmada, alanların farklı disiplinlerden yararlanarak kendini geliştirmesi ve gerçekleştirmesi gerekliliğine dayanarak, halkla ilişkilerin önemli uygulama alanlarından olan kriz yönetimine, "sosyal bilimlerin doğasına çeşitli şekillerde uygun anlam arayışları toplamı" (Saygın, 2009: 110) olarak nitelendirilebilecek hermeneutik gelenekten yararlanılarak alg1 temelli farklı bir bakış açısı getirilmeye çalışılmıştır. Kriz yönetimi açısından hermeneutik imkanların bilinmesi, algı açısından "anlaşılması güç" olguları, anlaşılabilir hale getirebilme imkanı sunabilmekte, hermeneutik problemler ise "anlaşılması kolay" olguları neredeyse anlaşılmaz hale getirebilmektedir. Bu nedenle, algı mefhumunun özellikle önem kazandığı kriz yönetimi konusuna hermeneutiğin entegrasyonu proaktif bir kriz yönetimi açısından oldukça faydalı olacaktır. Bu çalışmada, kriz yönetimi konusuna hermeneutiğin entegrasyonu açısından verilecek örneklerle konunun daha iyi anlaşılması sağlanacaktır.

\section{Hermeneutik}

\subsection{Hermeneutik Kavramı}

Hermeneutik (yorumsama, yorum sanatı, yorumbilim, yorumcu yaklaşım, yorum bilgisi) kelimesi Türkçede "hermenötik" ve "hermenoytik" olarak da kullanılmıştır. Hermeneutik Grekçe "hermeneuein" yani ifade etmek/bildirmek, açıklamak, tercüme etmek/çevirmek fiilinden türemiştir (Gadamer, 2003: 13). Latinceye "hermeneutica" olarak çevrilmiş ve Grekçe anlamlarının içeriği nedeniyle "yorum sanatı", "yorum tekniği" olarak anlaşılmıştır. Hermeneutiğin "yorum bilimi” şeklindeki ifadesine bilimin kendisine özgü objesinin ve yönteminin olması gerektiği, hermeneutiğin ise özel bir obje ve yönteminin olmadığı, anlam yüklenebilecek her şeyin hermeneutiğin konusu olabileceğini öne sürerek 
karşı çıkanlar olmuştur (Özcan, 2000: 10). Ancak Barnes, "diğer realistler gibi, her türlü bilimsel araştırmanın, hatta doğa bilimlerindeki araştırmaların bile yorumu gerektirdiği ve bu yüzden de "hermeneutik" oldukları tezine dayanan bir "post-empirisist" bilim anlayışı benimser. O, bu yeni bilimsel araştırma tanımını, genelde sosyal bilimlerin özelde de bilgi sosyolojisinin "bilimsel" olmadığını iddia edenleri çürütmek için kullanır" ve realistler yaptıkları çıkarımlar sonucu hem doğa hem de sosyal bilimlerin yorumu gerektirdikleri ve bu nedenle hermeneutik kategori altında sınıflandırılmaları gerektiği çıkarımında bulunmuşlardır (Hekman, 2012: 63-68).

Etimolojik olarak kavram Yunan mitolojisinde Tanrı Zeus ve Maia'nın oğlu olarak geçen Hermes'e dayanmaktadır. Hermes Yunan mitolojisinde Tanrılar ve insanlar arasındaki iletişimi sağlamaktadır (Dellaloğlu, 1998: 43 ve Erhat, 1989: 15). Bazı İslami kaynaklara göre ise Hermes İdris (a.s.)'dır ve yazının kaşifidir (İbn Hacer, 1990: 375). Hermes söz yoluyla ilişkiler kurmada, ses ile ikna etmede ve kandırma sanatında oldukça hünerlidir (Özcan, 2000: 14). "Hermes bir yorumcu veya bir haberci veya bir hirsız veya bir yalancı veya bir pazarlık yapan kişidir; bu türlerin büyük ölçüde sahip bulundukları her şey dille ilişkilidir" ve "doğal dilin "ustası olmayı" öğrendiğimiz ölçüde kazandığımız bir "yeteneğe/beceriye" atıfta bulunur: lengüistik olarak komünike edilebilir/iletilebilir anlamı anlama ve onu çarpık/tahrif edilmiş iletişim durumlarında kavranabilir hale getirme sanatı" olarak tanımlanır (Gadamer, 2002: 13-231).

İletişim, söylem, anlama, yorum ve dil becerisi gibi kavramların Hermes efsanesinden meydana geldiği söylenmektedir (Kurt, 1994: 1). Hermeneutik tercüme, yorumlama ve anlamanın farklılıkları uzlaştırma tecrübesinin adı olarak kullanılmıştır. Hermeneutikte içerik ne olursa olsun daima bir anlama isteğinde bulunulmaktadır (aktaran Özcan, 2000: 9-15). "Hermeneutik etkinlik, bir başka dünyaya ait anlam bağlamını, o an içinde yaşanılan dünyaya aktarma etkinliğidir" (Gadamer, 2003: 11). 2002: 73).

Hermeneutik geniş ve gelişen tanımıyla "yoruma dayalı anlama teorisi"dir (Arslan,

\subsection{Tarihsel Olarak Hermeneutiğin Gelişimi}

Antik dönemden beri var olan hermeneutik kavramının tarihsel olarak inkişafının üç ana hattı bulunmaktadır. Bunlar: 1. 18. yüzyıl kutsal kitap hermeneutiği ve teolojik hermeneutik. 2. Schleiermacher ve Wilhelm Dilthey tarafindan hermeneutiğin tinsel bilimlerin evrensel bir yöntemi haline dönüştürülmesi. 3. Hermeneutiğin “çağdaş dönemi” denilebilecek Gadamer'in hermeneutiğidir. (aktaran Alioğlu, 2007: 1195).

\subsubsection{Yüzyll Kutsal Kitap Hermeneutiği ve Teolojik Hermeneutik}

Aristoteles'in Peri Hermenias (Yorum Üzerine) kitabında düşünce ve düşünceyi dile getiren olgu arasındaki anlatımının birleşimi temelli çıkarımların türevleri bulunmaktadır (Ormitson ve Schrift, 2002: 14). Peri Hermenias yorumsama kavramının yazılı literatüre geçtiği ilk kaynaklardandır.

\subsubsection{Hermeneutiğin Tinsel Bilimlerin Evrensel Bir Yöntemi Haline Dönüştürülmesi}

Antik çağ sonrası orta çağda hermeneutik tarihsel bir dönüşüm geçirerek teolojik bir biçim almıştır. Bu dönüşüm bilinen ve işaret edilen anlam arasındaki ikilemin yerine Stoacı dış anlam ve iç anlam ikileminin geçmesiyle olmuştur. Teolojik hermeneutik bu Stoacı ikileme dayanır. Bu yaklaşım alegorik yönteme dayanmaktadır. Alegorik yöntemde bir ismin veya formülün avamın bildiği bir anlamı ve sadece seçkinlerin bildiği birden çok anlamı vardır. Philon bu yöntemi tanımlamamış ancak sözlü anlamın belirsizliğe veya yanlış anlamaya sebep 
olduğu durumlarda uygulamıştır. Philon'a göre kutsal kitapta lafzi anlam ve maddi olmayan sırları ortaya çıkarmak olan alegorik anlam vardır ve yorum sanatı harfin fizik yapısını aşarak üst anlamı ortaya çıkarmaktır. Bu ilişki beden ve ruh arasındaki ilişki gibidir. Bir manada bu yaklaşım metnin lafzından hareketle görülebilenin içinde görülemezi fark etmek demektir. (Özcan, 2000: 25-28). Luther'in "kutsal metinleri kendilerinden hareketle yorumlama" daveti de bu dönem için önemlidir (Gadamer, 2003: 16).

$\mathrm{Bu}$ dönemde hermeneutik "Katolik ve Protestanlık tartışmaları sırasında İncil'in nasıl anlaşılması gerektiğine ilişkin yöntemsel yaklaşım önerilerinin kutsal metinlerin yorumlanması ve daha açık kılınması gerektiğine dair sorunlarla gündeme gelmiş bir kavramdır ve doğru anlama ulaşma yöntemi olarak kabul edilmiştir" (aktaran Saygın, 2009: 104). Teolojik hermeneutik "metnin ne dediğini değil ne demek istediğini" anlama yoluna gitmiştir. $\mathrm{Bu}$ yaklaşımın doğmasının nedeni Hıristiyanlık metinlerinin orijinallerinin bulunmamasından kaynaklanmaktadır (Dartma; Demirci; Ünver vd. 2013: 242).

\subsubsection{Hermeneutiğin Çăğdaş Dönemi}

Ortaçağın sonlarında alegorik yöntem etkinliğini yitirmiştir. Friedrich D. Schleiermacher her metnin yorumu için işe yarayabilecek bir genel hermeneutik için çalışmalar yapmıştır. Ona göre "her ifade, kendi kökeninde, dil ve düşünce bütünlüğü olmak üzere çifte bir ilişkiye sahiptir; bu durumda bütün anlamalar iki andan ibarettir, dilsel ifadelerin anlaşılması anı ve düşünürün içinde bulunduğu durumun anlaşılması anıdır” (Taşdelen, 2008: 91). Hukuki, dini veya edebi tüm metinlerin dil içerisinde oluştuğu ve anlamının olduğunu ifade etmiş ve bu anlamın bulunabilmesi için gramere ihtiyaç olduğunu belirtmiştir (Palmer, 1969: 121). Schleiermacher hermeneutiği cihanşümul bir anlama bilimi haline getirme gayreti içinde olmuştur (Göka, 1993: 86). Hermeneutiği dogmatik yönlerinden arındırmaya gayret etmiştir (Gadamer, 2003: 17).

"Hermeneutiğin hukuktaki rolü, hiçbir genel kuralın, hukuk tecrübesinin ve pratiğinin bütün özel/bireysel durumları asla kuşatamayacağının farkına varılmasına dayanıyordu. Bir özel durumu bir genel yasa kapsamına yerleştirmek, her durumda bir yorumlama eylemidir" (Arslan, 2002: 151). Bu farkındalığın genel geçer tüm alanlarla ilgili de böyle olduğunu söylemek yanlış olmayacaktır. Alanı ne olursa olsun hiçbir genel kuralın bütün özel durumları kuşatması imkansızdır. Bu yüzden yoruma ihtiyaç vardır.

Schleiermacher hermeneutiği bir "anlama sanatı" olarak ifade etmiştir (Tatar, 2004: 37). Hermeneutiği özel bir disiplin çerçevesinden çıkararak herhangi bir şeyi anlama sanatı olarak değerlendirmiştir. Ona göre hermeneutik sadece yazılı metinlerin incelenmesi ile ilgilenmemekte, kişilerarası diyalogları da konu edinmektedir (Toprak, 2003: 38-41). Schleiermacher anlama ve yorumlamayı birbirinden ayırmış ve yanlış anlamanın önemine vurgu yapmıştır (Bilen, 2001: 63 ve Cevizci, 1999: 758). O genelleşmemiş birçok özel hermeneutiği birleştirdiğini ifade etmiş ve bir metni anlamak için metnin salt kendisinin yeterli olmayacağını, yazıldığı tarihi ve yazarı çevreleyen koşulları ve yazarın ruh halini de bilmek ve idrak etmek gerektiğini söylemektedir (Alan, 2008: 26 ve Taşdelen, 2008: 101). Bu nedenle gramatik yorumlama ve psikolojik yorumlama yöntemleri meydana gelmiştir (Öztürk, 2009: 154). Gramatik yöntem dil bilgisini, tümce yapısını ve semantiği incelemektedir (Toprak, 2003: 45). Psikolojik yöntem ise yazarı çevreleyen koşulları ve yazarın ruh halini idrak etmeye çalışmayı kapsar (Taşdelen, 2008: 93). Gadamer'e göre Friedrich D. Schleiermacher hermeneutiğin "büyük babası" olmakla birlikte, hermeneutiği yardımcı bir disiplin olarak algılanmaktan kurtaramamıştır (Gadamer, 2007: 361). Zira Gadamer Schleiermacher'in hermeneutiği ile ilgili şöyle demiştir: "Schleiermacher" in geliştirdiği hermenoytik evrensel olsa da bu evrensellik algılanabilir sınırlar içinde bir hermenoytikti" (Gadamer, 2008: 274). 
İlerleyen dönemde Wilhelm Dilthey (1833-1911) hermeneutiği bir sonraki aşamaya taşımış ve anlamanın tin bilimlerinin özelliği olduğunu belirtmiştir ve tin bilimlerinin hermeneutik yönteme ihtiyaç duyduğunu belirtmiştir (Gadamer, 2002: 151-152). Dilthey yorumun anlaşılabilmesi için öncelikle anlamanın anlaşılması gerektiğini belirtmiş ve "Duyularımıza dışarıdan verilen göstergeler aracılığıyla içerdekini tanıma sürecine anlamak diyoruz" demiştir (Özcan, 2000: 151). Dilthey'e göre "hermeneutik yazılı dokümanların yorum kuralları teorisidir" (Dilthey, 1996: 238). Schleiermacher'den farklı olarak Dilthey'in hermeneutik teorisine göre okuyucu anlamı yeniden yaratan bir dahidir (Doğan, 2006: 41-42). Max Weber bu teorinin etkisinde kalarak sosyolojiyi "toplumsal etkinliği yorumlama yoluyla anlamak" olarak tanımlamıştır (Weber, 1995: 10). Dilthey'e göre "Anlama da bir dereceye kadar sempatiye bağlıdır. Örneğin bize hiçbir şekilde sempatik gelmeyen insanları pek öyle kolayca anlayamayız. Buna karşılık bir tiyatro sahnesi önüne oturduğumuzda, sempatinin yeniden üretici/kurucu/oluşturucu anlamayla yakınlığı kendini çok daha açık gösterir. Oyunu izlerken artık sadece tasarlamayız, sadece algılamayız; hatta oyun kahramanlarının psişik hallerini yeniden yaşarız" (Dilthey, 1999: 37). Yani "anlama bir zihin halini, onun kendisiyle ifade edildiği anlam yüklenmiş bir göstergeden tanıma işlemidir” (West, 2005: 142).

Hans George Gadamer hermeneutik ile ilgili yaptığı çalışmalar ile hermeneutik anlayışını bir adım ileri taşımıştır. Ona göre hermeneutik kendi hakiki varlığını bulması için İncil' in tebliği gibi dogmatik amaçlara hizmet etmeyi bırakması gerekiyordu (Gadamer, 2008: 247). Gadamer'e göre anlama, yorumlama ve uygulama ayrı yöntemler değildir. "Anlamadan yorum yapilamaz diyen Dilthey'in aksine, Gadamer, anlamak her zaman yorumlamaktır görüşündedir" (Kasapoğlu, 1992: 63). Anlama bu üçünü de içermektedir. Anlama ile yorumlama iç içedir. Ona göre yorum metnin ufku ile yorumcunun ufkunun ("belirli bir hakim noktadan görülebilen her şeyi içine alan görüş alanı") (Gadamer, 2009: 56) hemdem olmasıdır (Kılıç, 2005: 98-99). Yorum öznel bir anlamadır (Taşdelen, 2008: 178). "Hermeneutik bilincin gerçek gücü, sorgulanabilir olan şeyi görebilme yetimizdir" (Arslan, 2002: 69).

Gadamer ayrıca ön-anlama kavramına vurgu yapmıştır: "Açıklayıcı yorum, açıklamanın bağlamsal, "ufuksal" olduğunu fark etmemizi sağlar. Açıklama, önceden varsayılan anlamlar ve niyetler ufkunda yapılır. Hermeneutikte, bu varsayılan anlamaya önanlama denir" (Richard, 1969: 24). "Gadamer modern bilimi kisitlamalar olmaksizin hermeneutiğe dahil etme uğraşı içerisindedir (Gadamer, 2008: XLII). Felsefi hermeneutiği ortaya koyarak, hermeneutiğin dünya tecrübesinin tamamında belirleyici bir rol oynadığına vurgu yapmıştır (Gadamer, 2007: 67). Bu noktada anlama yorumlayandan bağımsız olarak değerlendirilemeyecek bir olgu haline dönüşmüştür (Bernstein, 1986: 91). "Eğer bir şekilde anlıyor isek, farklı tarzda anladığımızı söylemek kafidir" (Gadamer, 2009: 48). Bu nedenle anlama tümüyle yoruma dönüşmektedir (Toprak, 2003: 133).

"Sonuçta hermenoytik uzmanlara gerekli bir teknik kehanetleri ve mucizeleri yorumlayanların techne hermeneutike'i olarak kalamaz; hermenoytik bir genel kavrama problemini de içerir" (Ricoeur, 2009: 4).

\subsection{Hermeneutik İle İlgili Kavramlar}

Hermeneutiğin tarihsel inkişafı çerçevesinde değerlendirildiğinde anlama ve yorum kavramlarının hermeneutik ile bizatihi ilgili olduğu görülmektedir. Richard Bernstein "Bizler anlayan ve yorumlayan bir varlık olarak acuna atılmış durumdayız." der (Bernstein, 2011: 113).

\subsubsection{Anlama ve Hermeneutik}

Rosenberg "Anlama, anlaşılması çok zor olan bir mefhumdur” (Petrot, 1981: 29) der. Roy Howard ise "Anlamayı anlama problemi” (Howard, 1982: 45) olarak ifade eder. Bilimsel 
veriye ulaşmanın yöntem olarak ana şartı anlamadır (Dellaloğlu, 1998: 121) ancak "anlama potansiyel olarak hep yanlışa açıktır" (aktaran Özcan, 2000: 153).

Max Weber bu düzenliliğin "bütün olguları, anlaşılır biçimde yorumlamamıza izin verdiğini”" (aktaran Özcan, 2000: 131) belirtmiştir. Dilthey "doğayı açıklarız, insani olayları ise anlarız" demiştir. (Dilthey, 1999: 76)

Hermeneutik anlama olayını derinlemesine araştırmayı mümkün kılmıştır. Anlama günümüzde insan bilimlerinin bir yöntemidir. Zira Dilthey'i müteakiben anlama "gerçekleştirilen", "yaşanan", "algılanan” ve "kabul edilen" olguların anlamlarını bilmeye çalışan bir yöntem olarak kabul görmüştür. Sosyolojinin anlama yönteminden beklentilerinin sonucunda beşeri hedefler ile ilgili olan her şey hermeneutiğe dahil olmuştur (Arslan, 2002: 132-133). "Eylemlerimiz her yerde, diğer insanların anlaşılmasını koşul olarak gerektirir. İnsan mutluluğunun önemli bir kısmı, diğer insanların psişik hallerine katılmaktan, bu psişik halleri kendimizde hissedip yaşamaktan kaynaklanır" (Dilthey, 1999: 91). Anlama ancak "daha önceden mevcut olan bir tasavvurun derinleştirilmesi" ile gerçekleşir. Anlamak için anlaşılması istenen olgunun muhtevası tüm ayrıntıları ile incelenmelidir (Bollnow, 1995: 105). Ayrıca her bireyin "iç tecrübesi" kendisine özgü olduğundan anlama sübjektiftir (Özcan, 2000: 142-143). "Duyularımıza dışarıdan verilen göstergeler aracılığıyla içeridekini tanıma sürecine anlamak, diyoruz" (aktaran Özcan, 2000: 151). Bu çerçevede anlama kreatif bir biçimde yeniden oluşturmadır (Göka, 1993: 86). Yani "anlama, tamamen sahip olduğumuz ön yargılar aracılığıyla" (Vesek, 2004: 47) ve "yaşama-nesneleşme yoluyla" gerçekleşir (İnalcık, 2002: 14). "Anlama yeteneği insanın doğuştan gelen temel kabiliyeti, başkalarıyla komünal hayat destek sağlayan, daha da önemlisi, dil ve diyaloga katılım yoluyla ortaya çıkan kabiliyetidir" (Gadamer, 2002: 285).

Seyyid Ahmet Arvasi "Kendini Arayan İnsan" adlı eserinde bu konuyu şöyle açıklamaktadır " ..., insan zihni, düz bir ayna gibi kendine gelen etkileri ve verileri aynen yansıtmıyor. Onları kendi belleğinde yoğuruyor ve öylece ortaya koyuyor” (Arvasi, 2009: 43).

"Dilthey'e göre anlama, bir zihnin içinde ötekinin zihinsel nesnelleştirmelerinin farkına vardığı süreçtir. Anlama Ben'in Sen'de yeniden keşfidir" (Arslan, 2002: 13). Çağdaş hermeneutikte anlama yorum ile iş birliği içerisinde olan, estetik, etik politik, dini veya pedagojik kavramaya çalışan ve müjdeleme, bildirme, yorumlama tercüme veya deşifre etme gibi olguların arasındaki ilişkiyi ifade etmek için kullanılmaktadır (Özcan, 2000: 157). “Anlama, tüm yorumlamaların temelidir" (aktaran Vesek, 2004: 44).

Hermeneutikte anlamanın bir amacı da "yazarı bizzat kendinin anladığından daha iyi anlamaktır" (Dilthey, 1999: 113) "Felsefi yorumbilim (philosophical hermeneutics) açısından yorum, "bir metnin anlamını keşfetmek değil", "bir metnin anlamını inşa etmektir". Dolayısıyla felsefi yorumbilimde yorumun, kurucu (constructive) bir işlevi vardır" (aktaran Aktaş, 2011: 2)

\subsubsection{Yorum ve Hermeneutik}

Yorum metindeki ipuçlarından yola çıkar. Yorumcu metinde üstü kapalı bir şekilde ifade edilen, açık bir şekilde görülmeyen gizli anlam veya anlamlara ulaşmak için ipuçlarını birbirine bağlar. Yorum dış ifadeye nüfuz ederek onun iç anlamına ulaşmaya çalışır. Kesin olmamak ve bilgisiz olmak yorumcuyu harekete geçirmektedir. Yorum üzerinde arzular kültür, tarihi miras gibi birçok unsurun etkisi olabileceğinden yorum alanı peşin hükümlerden arındırılmış değildir. Yorum ön-anlama ile başlar. Ön-anlama düşünme şeklini sınırlamaktadır. Zaman zaman hayat gerçekliği ile yorum gerçekliği arasında farklılık olabilmektedir (Özcan, 2000: 195-203). "Açıklayıcı yorum, açıklamanın bağlamsal, "ufuksal" 
olduğunu fark etmemizi sağlar. Açıklama, önceden varsayılan anlamlar ve niyetler ufkunda yapılır. Hermeneutikte, bu varsayılan anlamaya ön-anlama denir" (aktaran Ataman, 2007: 10).

Hermeneutiğin sistematik bir teorisi bulunmamakla (Geltsetzer, 1997: 95) birlikte hermeneutik açıdan iki farklı yorumdan bahsetmek mümkündür. Bunlar "Gramatikal Yorum" ve "Teknik Yorum"dur.

Gramatikal yorum "o, dilden hareketle ve dil yardımıla bir söylemin kesin anlamını bulma sanatıdır" ve "her şeyden önce objektif bir açıklama söz konusu olduğunda uygulanır ve yazarın toplu düşüncesinden çok, düşüncenin ifade edildiği öğeler üzerinde yoğunlaşır." "Gramatikal yorumun objektiflik ve negatifliğine karşıt olarak teknik yorum, sübjektif ve pozitiftir. Burada anlamanın konusu konuşan kişidir” (aktaran Özcan, 2000: 227).

"Hayati önem taşıyan yapıtların yorumu ile ilgili farklı düşüncelerin savaşından ve yorum sanatının kurallarını temellendirmek için duyulan şiddetli ihtiyaçtan 'hermeneutik' bilimi doğmuştur" (Kasapoğlu, 1992: 60). Bazı kaynaklar yorumun genel itibariyle "metnin ortaya koyduğu hakikati tecrübe etmek" olduğuna vurgu yapar. Buna karşın niyetselcilere göre doğru yorumunun yegane temeli yazarın niyetidir. Bu anlayış, metni anlamanın ölçütü olarak yazarın niyetini alır. Bu nedenle niyetselci olarak ifade edilmektedir. Gademer niyetselci anlayışa karşı çıkar ve metnin anlamının yazarın niyetini aştığını ifade eder. Ancak metnin anlamının yazarın niyetini aşması konusu diğer taraftan hakikati kendi bakış açımıza indirgeme sorununu ortaya çıkarmaktadır ve problemin temeli yorumda görecelik ve nesnellik tartışmalarının kaynăğındadır (Tatar, 2004: 9-19).

"Diğer yandan kişinin iradesinin yorumunda, o kişiye özgü duygusal ve sübjektif tercihlerin ön plana çıkması ve bunların anlaşılmaya çalışılması yorum yapılırken belirli bir kurala bağlanmayı engellemektedir" (aktaran Demir, 2013: 1153). Bu nedenle "aşırı yorumcu" yaklaşım diğer yorum ve anlama kavrayışlarını büyük ölçüde reddederek, metnin hiçbir nesnel ölçütü olmadığını ve anlamın tamamen anlamayı gerçekleştirecek kişi ile ilgili olduğunu savunur. Bu yaklaşıma göre doğru veya yanlış bir yorum yoktur, yorumun bir standardı bulunmamaktadır ve mühim olan yorumun ustalığıdır (aktaran Saygın, 2008: 3). Michelle de Montaigne ise çoğu yorumunun doğruyu buharlaştırarak yok ettiğini söylemektedir (Arslan, 2002: 2).

\section{Kriz Yönetiminin Hermeneutik Boyutu}

\subsection{Kriz, Kriz Yönetimi ve Hermeneutik Problemler}

"Şirketler kimi zaman teknik yönlere odaklanıp algılama sorununu görmezden gelerek bir problemi yanlış sınıflandırırlar. Oysa çoğu zaman krize yol açan şey kamuoyundaki algılamadır" (Augustine, 2000: 24). Kimi zaman krizler kurum tarafindan verilen bazı mesajların, yapılan bazı eylemlerin vb. yorumsanması (hermeneutik) sonucu oluşan algıdan kaynaklanabilmektedir. Aslında hermeneutik açıdan anlama mesaja maruz kalan kişinin mesajı daha önce edindiği bir dizi karmaşık bilgi ve duyguları yorumlamasıyla gerçekleşmektedir. Bu nedenle verilen her mesaj hermeneutiğe maruz kalacaktır demek yanlış olmayacaktır. Ancak kurum tarafından verilen mesaj, kurumun mesajının ulaştığı kitlelerde çeşitli nedenlerden dolayı arzu edilmeyen anlamlar oluşturuyor ise bir krizle karşı karşıya kalma ihtimali var demektir. Zira arzu edilmeyen anlamlandırma beklenmedik tepkiler doğurabilir. Burada arzu edilmeyenden kasit kurumun kesinlikle arzu etmediği ve muhtemelen aleyhine olacak bir biçimde anlaşılmasıdır. Nitekim Hermeneutik süreç "spekülatif düşünme" ve "içkin anlamın keşfedilmesi, analizi ve daha da geliştirilmesi" gibi kavramlarla da tanımlanmıştır (Arslan, 2002: 136). Ayrıca konu bu bağlamda değerlendirilirken mitolojik anlamda Hermes'e yapılan "bir haberci veya bir hırsız veya bir yalancı veya bir pazarlık yapan" gibi yakıştırmalar da unutulmamalıdır. 
Yorumsama / yorum sanatı / hermeneutik hukuki alanda genel kuralları özel/bireysel durumlara indirgerken çözüm amaçlı kullanılmaktadır. Ancak hermeneutik hukuki alanda krizlere de yol açabilmektedir. Örneğin 2007 Cumhurbaşkanlığı seçimleri esnasında eski Yargıtay Cumhuriyet Başsavcısı Sabih Kanadoğlu Anayasanın 102. Maddesine getirdiği farklı bir yorum sonucu ilk tur seçimlerinde seçilebilmek için toplantı yeter sayısının 367 olması gerektiği yargısına varmıştır. Bazı akademisyenler ve muhalefet parti milletvekilleri bu yorumu desteklemiş ve bu doğrultuda bazı milletvekilleri meclis oturumuna katılmamışlardır. $\mathrm{Bu}$ nedenle toplantı yeter sayısına ulaşılamadığı kanaatiyle 11. Cumhurbaşkanı seçilememiş ve genel seçime gidilmek zorunda kalınmıştır. Hukuki bir maddenin yorumsanması sonucu konjonktürün de uygun olması nedeniyle bir kriz ile karşı karşıya kalmıştır. Bu süreç kamuoyuna "367 krizi” olarak yansımıştır.

Hermeneutik hukuki alanda olduğu gibi diğer tüm alanlarda da krizlere neden olabilmektedir. Kernisky krizi "bir örgütün beklentileri ile çevresinde gerçekleşenler arasındaki büyük uyumsuzluk" (aktaran Akdağ, 2005: 3) olarak tanımlamaktadır. Hermeneutik açıdan bu uyumsuzluk, kurumun ilettiği/iletmeye çalıştı̆̆ mesaj ile alıcıların "anlam"ları arasında olan uyumsuzluk olarak değerlendirilebilir. Bu uyumsuzluğun ölçüsü ile orantılı olarak kriz olasılığı artacaktır.

Hermeneutik, anlam içeren her şeyi kapsamaktadır. Bu nedenle uyumsuzluk mesajın kendisiyle ilgili olabilir ancak salt bunu kapsamamaktadır. Zira yorum ön-anlama ile başlamakta ve ön-anlama düşünme biçimini sınırlayarak kimi zaman yorum gerçekliği ve hayat gerçekliği arasında farklar oluşturabilmektedir. Bu ön-anlamda kurumun kendisi ve mesaj1 ile ilgili olan veya olmayan bir dizi karmaşık olgu yer alır. Ayrıca yorumsama salt mesaj ile ilgili olmayabilir. Hatta ortada verilmek istenen bir mesaj bile olmayabilir. Ancak bu yorumsanmaya maruz kalmamak anlamına gelmez. Zira "kendisi dil öğesi içermeyen şey, dilsel yoruma muktedirdir" (aktaran Ataman, 2007: 17).

Arzu edilmeyen biçimde anlaşılabilecek ve yorumsanabilecek bu mesajların yorumsaması kurumun rakipleri, basın mensupları, sivil toplum örgütleri, siyasiler, hedef kitle ve/veya diğer şahıslar tarafından yapılabilir. Arzu edilmeyen yorumsama gayri ihtiyari yapılabileceği gibi bilinçli de yapılabilir. Gayri ihtiyari yorumsama kolektif şuurdan kaynaklanabilir. Kurum mesajını iletenlerin mesajın alıcılarının anlamlandırma sürecini bilmemeleri veya önemsememeleri böyle bir durum meydana getirebilir. Bununla birlikte kurumun krizle karşı karşıya kalması hatta yok olmasından çıkar elde edebilecek rakip kuruluşlar, siyasiler, kurumun bir eylemine veya tüm varlığına karşı çıkan sivil toplum örgütleri ve/veya basın kuruluşları bilinçli bir şekilde arzu edilmeyen yorumsama yoluna gidebilirler.

Özellikle basın kuruluşları tiraj kaygısı gütmekte; kriz etkisi oluşturabilecek olağandışı haberler dikkat çekici haberler olarak nitelendirilmekte ve tiraj kaygılarına çözüm olarak değerlendirilmektedir. Bu "sansasyon yoksa haber de yok" (Hürriyet, 2018) anlayışına sahip basın kuruluşları aşırı yorumcu bir tutum alabilir. Zira "kriz dönemlerinde kamuoyunun çoğunluğu açısından örgütle ilgili elde edilecek bilgi ve bilginin içine katılacak yorum, daha çok medya aracılığı ile sağlanmaktadır" (Pira-Sohodol, 2012: 219). Bu nedenle "Basınla ilişki içindeyken, tutulan yol ne olursa olsun, kontrolü elden bırakmamak, durumu abartmamak, kimseyi suçlamamak, argo ve mesleki terimleri mümkün olduğunca kullanmamak ve dürüst olmak gerekir. Kriz anında "yorum yok" sözü en tehlikeli mesajdır. Hedef kitleler dürüst, sempatik, şefkatli, açık, kolay anlaşabilen, tarafsız, samimi, uygun zamanlı ve kendilerine kibarca hitap edip takdirle yaklaşan mesajlar duymak isterler. Burada amaç, hedef kitleleri ve basını anlamak ve dolayısıyla etkilemektir" (Pira-Sohodol, 2012: 227) denilmektedir. Ancak bu yeterli olmayabilir. Zira her ne kadar açık, kibar ve sempatik mesajlar iletilmeye çalış1ırsa 
çalışsın, insan doğası ve hermeneutik gaye gereği mesaj sahibinin kendisinin anladığından da daha iyi anlamaya çalışılabilir. Zira hermeneutikte anlamanın bir amacı da "yazarı bizzat kendinin anladığından daha iyi anlamaktır" (Dilthey, 1999: 113). Bu nedenle arzu edilmeyen yorumsamayı yapanlar, kurumu salt mesajın sınırlarını aşarak kendinden daha iyi anlayabilir veya anladığını iddia edebilir. Açıkça dile getirilmese bile mesajın yorumsanmış haliyle sizi sizden daha iyi anladığı imasında bulunabilirler.

Bilinçli bir şekilde ve kurum aleyhine yapılabilecek yorumsamayı yapacak kişilerin (rakip kuruluşlar, siyasiler, kurumun bir eylemine veya tüm varlığına karşı çıkan sivil toplum örgütleri ve/veya basın kuruluşları), gayri ihtiyari bir şekilde olumsuz yorumsama yapabilecek kitlelere göre daha nüfuz sahibi ve görece daha profesyonel oldukları varsayımı yapılabilir. Ancak günümüzde yorumsamanın özgünlüğüne de bağlı olarak sosyal medya imkanları ile bu erk eşitsizliği görece daha azdır.

Anlama sübjektif olmakla birlikte, ortak bilgi ve kültürle beslenmiş gruplar benzer anlamlara ulaşabilir ve benzerlik gösteren tepkiler verebilirler. Kriz yönetimi açısından değerlendirilmeye tabi tutulabilecek olgu budur. Yani belirli grupların kolektif paradigmaları, ön-anlamları ve algıları. Tüm "anlama"lar yoruma dayalıdır. Bu nedenle kriz yönetiminin en önemli hedeflerinden biri olarak anlaşılmak olgusuna vurgu yapıldığ takdirde hermeneutik anlamayı, yorumsamanın nasıl ve neden gerçekleştiğini, arzu edilmeyen ve aşırı yorumsamadan kaçınmak için nelere dikkat edilmesi gerektiğini bilmek ve uygulamak kriz yönetimi açısından önemlidir. Özellikle kurumların sosyal medyayı aktif bir şekilde kullanmaya başlamasıyla birlikte hermeneutik probleme dayalı krizler artmaktadır. Zira sosyal medya doğası gereği yüksek düzeyde serbestlik ihtiva eden bir mecradır. Sosyal medyanın bu nispeten daha rahat ortamı ve hızlı kullanım gereksinimi kurumların mesajlarını veya sundukları materyalleri geleneksel yöntemlere göre daha hazırlıksız bir şekilde sunmalarına neden olmaktadır. Hazırlıksız olma yani mesajın veya sunulan materyalin üzerinde yeterince çalışılmamış olması mesaj veya materyalin yorumsama açısından oldukça elverişli olduğu anlamına gelebilmektedir. Öyle ki çoğu zaman sosyal medya üzerinden yayınlanan mesajlar o işle görevlendirilen kişinin anlık mesajları olarak karşımıza çıkmaktadır.

Tüm krizlerin hermeneutik boyutu vardır. Krizin kaynağı iletilen bir mesaj olsun ya da olmasın her iki durumda da ön-anlama kullanılarak yapılan bir yorumsama sonucu oluşan alg1 söz konusudur. Hermeneutik problemler bir kriz meydana getirebileceği gibi, başka bir nedenle meydana gelen bir kriz esnasında yaşanacak bir hermeneutik problem krizin boyutunu büyütebilir.

Proaktif bir kriz yönetimi anlayışı için hermeneutik imkanlardan yararlanmak oldukça faydalı olabilir. Sorun analizi, değerlendirme ve özellikle ortak bir nokta yakalamak için önanlam, yorum, yorumsama gibi hermeneutik kavramları bilmek ve onlardan yararlanmak faydalı olacaktır. $\mathrm{Bu}$ olgular değerlendirilerek hazırlanacak kriz planları ve uygulamalar proaktif sürece katkı sağlayacak ayrıca ön-anlama, anlama yorumsama gibi kavramların algı ile ilgili kavramlar ile paralellik göstermesi nedeniyle, algı kontrolü ve alg1 yönetimi açısından da eşsiz materyaller sunacaktır.

\subsection{Süreçsel Olarak Hermeneutik ve Kriz Yönetimi}

Kriz yönetimi açısından mesaj hazırlanırken ve iletilirken alıcıların dikkate alınması gerekir (Örnek-Aydın, 2007: 116). Gerek mesaj iletilirken gerekse diğer eylemler planlanırken alıcıların dikkate alınması oldukça önemlidir ve hermeneutik ile alıcıların derinlemesine dikkate alınması mümkündür.

Süreçsel olarak hermeneutik ve kriz yönetimi konusu kriz ile paralel olarak üç evrede ele alınacaktır. Bu evreler: "Kriz Yönetiminde Kriz Öncesi Dönem ve Hermeneutik", "Kriz 
Yönetiminde Kriz Dönemi ve Hermeneutik" ve "Kriz Yönetiminde Kriz Sonrası Dönem ve Hermeneutik"dir.

\subsubsection{Kriz Yönetiminde Kriz Öncesi Dönem ve Hermeneutik}

Kriz öncesi dönemde kriz yönetimi genel itibariyle kriz sinyallerinin alınıp değerlendirilmesi, erken uyarı sistemlerinin devreye sokulması, kriz planının oluşturulması ve kriz yönetim ekibinin belirlenmesi gereken bir süreçtir.

Hermeneutik problemlerin yaşanmaması için bu dönemde alınabilecek bazı tedbirler vardır. Öncelikle kriz yönetimi ekibi de dahil olmak üzere kurumun iletişim ve imaj çalışmalarını gerçekleştiren tüm çalışanları anlama, yorum, yorumsama kavramlarını bilmeli, anlama ve yorumsama sürecinin nasıl gerçekleştiğini idrak etmeli, özel görevlendirilmiş uzman kişiler ise ilgi gruplarının (kurumun rakipleri, basın mensupları, sivil toplum örgütleri, siyasiler, hedef kitle) ön-anlam - yorum - anlam süreçlerini yani hermeneutik süreci sürekli olarak araştırmalı ve kriz yönetimi planı bu araştırmalar sonucu ortaya çıkan sonuçlar dikkate alınarak hazırlanmalıdır. Zira bu araştırmaların verilecek mesajların ne şekilde olması gerektiği, hangi davranışların sergilenip sergilenmemesi gerektiği ile ipuçları vereceğini ummak yanlış olmayacaktır. Yaşanabilecek hermeneutik problemler daha önce kurum içinde veya kurum dışında benzer hermeneutik problemler ile kıyaslanarak değerlendirmeye tabi tutulmalıdır. Özellikle ön-anlamlandırmada meydana gelen değişimler analiz edilerek, bu değişimlerin kurumu ne şekilde etkileyebileceği araştırılmalıdır. Özgünlüğü olmayan, hedef kitlenin hermeneutiksel süreci değerlendirilmeden yapılacak basmakalıp uygulamalar krizlere neden olabilir. Özellikle kolektif yorumsamanın ne şekilde gerçekleşeceğini doğru analiz etmek krizi firsata çevirmek için oldukça faydalı olacaktır. Zira "Hermeneutik aynı zamanda bir geleneğin, söylenmiş bir şeyin vb. doğru sayılmasının nedenlerinin incelenmesine de ilgi duyar" denilmektedir (Arslan, 2002: 92).

Hermeneutik açıdan sinyallerin alınması için kriz yönetimi ekibinin şu sorulara cevap vermesi faydalı olacaktır.

- $\quad$ O güne kadar yaşanan hermeneutik problemler veya krizler var mıdır? Var ise bu problemin kaynağı nedir? Problem çözülmüş ise ne şekilde çözülmüştür?

- $\quad$ Yapılan hermeneutik süreci değerlendirme sonuçlarına göre kurumun hali hazırdaki bir mesaj veya eyleminin arzu edilmeyen bir şekilde yorumsamaya maruz kalma ihtimali var midir?

Sahipse bu anlamlar nelerdir?

Kurumun hali hazırdaki mesajları veya eylemleri çokanlamlılığa sahip midir?

- $\quad$ Kurumun hali hazırdaki mesajları veya eylemleri özellikle yakın dönem geçmiş ile tutarlılık sergilemekte midir?

$\mathrm{Bu}$ ve benzeri soruların cevapları bulunmaya çalışarak olası bir hermeneutik krizin sinyalleri alınarak önlemler alınmalıdır. Kurumun kriz yönetimi kapsamında hazırlayacağı tüm materyal, yazılı veya yazılı olmayan önlemler gibi unsurların tamamı bu olgular çerçevesinde değerlendirilerek hazırlanmalıdır. Artık "Yanlış Anlaşıldık" deme dönemi kapanmıştır. Zira yeni medya algısı ve kamuoyu bunu kabul etmemektedir (Hürriyet, 2018).

Özellikle arzulanmayan biçimde yorumsanabilecek çokanlamlılıktan kaçınmak çok önemlidir. Kurumunuzun ilettiği bir mesajın veya meydana getirdiği bir icraatın böyle bir çokanlamlılık taşıması hermeneutik problemler oluşturabilir. Muhtemel krizler irdelenirken mümkün olduğunca çok kişi ile görüşmek faydalı olacaktır. Zira risk algısı kişiden kişiye değişkenlik gösterir (Luecke, 2009: 14). Bu hermeneutik açıdan da böyledir. Yorumsama ve 
anlamanın sübjektifliği nedeniyle mümkün olduğu kadar çok kişiyle görüşmek, mesajları ve olayları bu kişilerin nasıl yorumsadığını incelemek faydalı olacaktır.

Kriz öncesi dönemde bu veriler dikkate alınarak hazırlanacak kriz yönetim planları ve iletişim stratejileri hermeneutik bir problem ile karşılaşma ihtimalini azaltmaya yardımcı olabilir.

\subsubsection{Kriz Yönetiminde Kriz Dönemi ve Hermeneutik}

Kriz anında kriz yönetiminin hermeneutik boyutundan bahsetmek için öncelikle krizi oluşturan etken incelenmelidir. Kriz yönetimi açısından krizi oluşturan etkenler kurum içi ve kurum dışı etkenler ana başlıklarında toplanmaktadır. Kriz yönetimi ve hermeneutik açısından incelendiğinde ise "hermeneutik probleme bağlı olan" ve "hermeneutik probleme bağlı olmayan" etkenler olarak adlandırmak mümkündür.

İş güvenliğinin sağlanmamış olması nedeniyle ölümlerin gerçekleştiği bir olayın doğurduğu bir krize hermeneutik etkenli bir kriz demek doğru olmaz. Hermeneutik açıdan böyle bir olayda elbette yorumsanacaktır. Zira anlama yorumsama ile olmaktadır. Ancak burada krizin temeli bir hermeneutik problem değildir.

\subsubsection{Hermeneutik Probleme Bağlı olan Kriz Döneminde Kriz Yönetimi ve Hermeneutik}

Konuyla ilgili şu iki hermeneutik temelli varsayım oldukça önemlidir: "Bir metin birinin kastettiği anlamı temsil etmek zorundadır- şayet değilse, bu durumda yorumcunun" ve "Okurun kavradığı anlamlar ya yazarla birlikte paylaşılan anlamlar ya da sadece okura ait olan anlamlardır" (aktaran Tatar, 1999: 20-21).

$\mathrm{Bu}$ varsayımlara göre her mesaj, simge, eylem, durum bir anlamı temsil etmek zorundadır. $\mathrm{Bu}$ anlam ona onu oluşturan tarafından yüklenmiş olabileceği gibi yorumcu tarafından da yüklenmiş olabilir. Ayrıca okurun/mesajın muhatabının kavradığı anlamlar mesajın kaynağının paylaştığı anlamlardan farklı olabilir. Her hermeneutik form aynı zamanda bir "kuşku bilincini aşma” formudur (Arslan, 2002: 149).

Hermeneutik temelli bir kriz örneği için Adalet ve Kalkınma Partisi genel merkez binasında yer alan simge verilebilir.

$\mathrm{Bu}$ simge özellikle sosyal medyada Yahudiliğin ve Museviliğin simgesi olarak görülen Davut Yıldızı'na benzetilmiş, bu şekilde yorumsanmış ve bir sosyal medya krizi doğmuştur. Oysa Davut Yıldızı olarak bilinen sembol altı köşeli olmasına karşın bina üzerinde yer alan yıldızlar sekiz köşelidir. Sekiz köşeli yıldızın ise Davut Yıldızı ile hiçbir ilgisi bulunmayı Selçukluda da kullanılan bir Türk sembolüdür. Türk Mimarisi'nde kümbetler, türbeler ve camiler başta olmak üzere birçok yerde kullanılmıştır (Büyükçanga, 2008: 12301234).

Sekiz köşeli yıldızın yanlış ve arzu edilmeyen şekilde yorumsanması ve buna benzer yorumsamalar krizlere yol açabilmektedir. Görüldüğü gibi bu olayda mesajın muhatabının kavradığı anlamlar mesajın kaynağının paylaştığı anlamlardan farklıdır.

Öncelikle Davut Yıldızı ve sekiz köşeli yıldız arasında benzerlik, özellikle ilk bakışta çok yüksektir. Her ne kadar bu bir Davut Yıldızı olmasa da yorumsamaya maruz kalma ihtimali değerlendirilerek kullanılmaması böyle bir krizin oluşumunu engelleyebilirdi. Zira "Elbette bazı anlam bozuklukları olabilir. Ama bunu teşvik etmenin gereği yoktur" (PiraSohodol, 2012: 226). Zira hermeneutik problem bir yanlış yorumsamadan kaynaklansa bile, 
bunu düzeltmek vakit ve nakdi kayba neden olacaktır. Ayrıca krize neden olan hermeneutik sorunsalının ulaştığı kesimlerin tamamına ulaşmak ve yanlış yorumsamayı gidermek oldukça zordur. Nitekim "kara haber tez duyulur". Basın, rakip kuruluşlar vb. kurumun savunmasını ve yanlışı düzeltme çabalarına kriz oluşturabilecek kurum aleyhine haberleri yaymada gösterdiği çabayı göstermeyebilir. Bu nedenle bir eylem veya mesaj uygulamaya konmadan önce "haklı olmak", "haklı olmamak", mesaj veya eylemin "doğru" veya "yanlış" olması yeterli değildir. Söz konusu mesaj veya eylemin hermeneutik bir probleme yol açıp açmayacağ 1 da değerlendirilmedir.

Hermeneutik temelli bir diğer kriz örneği Procter and Gamble (P\&G) şirketinin yaşadığı krizdir. Şirket 1981 yılında oldukça yoğun bir şekilde şirketin "şeytanla bağlantısı" konusunda bilgi isteyen mektuplar alıyordu. Şirketin şeytan ile bir ilişkisi olduğuna dair yorumsamanın sebebi şirket logosunun ayna yansımasına bakıldığında ortaya çıktığı iddia edilen 666 rakamıydı. Zira bu rakam "anti İsa" işareti olarak bilinmekte ve logonun bir şeytana tapınma ayinini sembolize ettiği söylenmekteydi. $P \& G$ şirketi bu hermeneutik problemi gidermek için yüksek çaba ve özveri harcamıştır (Narbay, 2006: 128-129).

P\&G şirketinin karş1laştığı kriz, hermeneutikte yorumcunun üstü kapalı bir şekilde ifade edilen, açık bir şekilde görülmeyen gizli anlam veya anlamlara ulaşmak için ipuçlarını birbirine bağlama çabasından kaynaklanmaktadır (Özcan, 2000: 195-203).

Bir kuruma veya şirkete ait olan ve subliminal bir mesaj taşıdığı iddia edilen birçok obje aslında aşırı yorumsama ürünüdür. Zira yorumlanma riski bilmece, gizem ve kehanetle bağlantılar yaratmaktadır (Arslan, 2002: 43).

Royal Dutch/Shell firması işlevini tamamlayan Brent Spar petrol platformunu Atlantik Okyanusu'nun diplerine batırma kararı aldı. Çevreciler genel olarak bu batırma planına hoşgörülü davranmışlar ve hükümetin onayı da alınmıştı. Bu süreçte Greenpeace protestocuları bir helikopterle eylem yapmak amacıyla platforma inmeyi denemişler ve bu girişime karşı Royal Dutch/Shell firması su toplarıyla helikopteri uzaklaştırmaya çalışmıştır. Bu olay hermeneutik sapmanın önemine vurgu yapmak için oldukça önemlidir. Zira platformu batırma planı hemen hemen tüm çevrelerce makul bir plan olarak görülmekte iken bir anda yoruma bağlı anlama ortaya çıkan görüntüler nedeniyle değişmiştir. Nitekim olay Wall Street Journal'da şu şekilde yer aldı: "Shell stratejik bir hata yaptı. Yeni iletişim dünyasının izleyicilerinin belleğinde kalan görüntü şu oldu: Dev bir çokuluslu petrol şirketi kamuoyunda cesur ve kararlı olarak tanınan küçük bir grubu geri püskürtmek için tüm gücünü kullanıyordu" (Augustine, 2000: 25-26). İște bu algı durumun gerçekliğini dikkate almaksızın ön-anlamlara dayalı bir yorumsamadan kaynaklanmaktadır. Şirketin platformu batırma planı bu hareket öncesi makul algılanırken, yapılan bu hareket hermeneutik bir sapmaya yol açarak hem batırma planı hem de şirket aleyhine bir anlam üretmiştir.

Hermeneutik bir problem sonucu krizle karşı karşıya kalan şirketlerden biri de Starbucks'tır. Sosyal medyayı etkin bir şekilde kullanan ve şeffaf olmaya özen gösteren şirketin www.twitter.com üzerinden paylaştığı bir açıklama hermeneutik probleme yol açarak bir kriz meydana getirmiştir. Açıklama şu şekilde idi "Elimizdeki stokların geçici olarak tükenmesine paralel olarak, bazı işletmelerimiz Arjantin'de üretilen bardakları kullanmaktadır. Özür dileriz." Bu ifadeler milliyetçiliğin giderek yükseldiği Arjantin'de Arjantin mallarının kalitesiz olduğu ve dolaylı olarak Arjantin'in küçümsendiği şeklinde yorumsandı. Devasa bir kriz ile karşı karşıya kalan şirket bir gün içerisinde 12000'i aşkın olumsuz cevap aldı ve sonuç olarak şirket özür dileyerek konunun yanlış ifade edildiğini bildirdi (DÜNYA, 2018).

İfadeler üzerinde yorumsamaya giderek şirketin söylemiyle ilgili çok farklı bir yorumsama yapılabilir. Örnek: "Elimizdeki stokların geçici olarak tükenmesine paralel olarak, 
bazı işletmelerimiz Arjantin'de üretilen bardakları kullanmaktadır. Özür dileriz." Yorumsamayı yapan kişinin ön-anlam algısını lümpen olguların çevrelediğini varsayalım. Bunun dışındaki algılar; Şirket çok büyük ve uluslararası bir şirkettir. Dünya çapında standardizasyon yakalamış bir şirkettir. Öyle ki Arjantin'de şirketin bir şubesinde içtiğiniz kahveden aldığınız tadın aynısını şirketin Kayseri şubesinde içtiğiniz kahvede de alabilirsiniz. $\mathrm{Bu}$ olgular doğrultusunda yorumsama: Starbucks firması, orijinalitesi olmayan, yakaladığ1 standartlara uymayan bardakları kullanmak zorunda kaldığı için çok değer verdiği Arjantinli müşterilerinden özür dilemektedir. Bu özür aynı zamanda dünya çapında sağladığı standardizasyonun garantörü niteliğindedir.

Görüldüğü gibi hermeneutik problemin temelini oluşturan çok-anlamlılık olgusu, hermeneutiğin sübjektif oluşu, ön-anlamlar vb. birbirine taban tabana zit anlamlar oluşturabilmekte ve krizlere neden olabilecek büyük problemler meydana getirebilmektedir. Eğer hermeneutik probleme dayalı bir krizle karşılaşılmış ise kriz öncesi dönemde hermeneutik ile ilgili tedbirlerin alınmadığı, uygulanmadığı, önemsenmediği veya bu tedbirlerden bihaber olunduğunu söylemek yanlış olmaz.

$\mathrm{Bu}$ dönemde krizin kaynağını oluşturan hermeneutik problem tespit edilmelidir. Hermeneutik problemin kaynağı yani hermeneutik probleme sebep olan mesaj veya eylem tespit edildikten sonra, yorumsamanın kaynağı tespit edilmelidir. Yorumsamanın kamuoyu tarafından gayri ihtiyari olarak mı gerçekleştiği yoksa kurumun rakipleri, basın mensupları, sivil toplum örgütleri, siyasiler gibi gruplar tarafından bilinçli bir şekilde mi yapıldığ 1 tespit edilmelidir. Yorumsamanın kaynağı olan ön-anlam veya anlamların ne olduğu tespit edilmeye çalışılmalıdır.

$\mathrm{Bu}$ tespitler mümkün olan en kısa süre içerisinde yapıldıktan sonra hermeneutik problemi düzeltmek için eylem veya mesaj yeniden şekillendirilmeli, çokanlamlılık giderilmelidir.

Kriz dönemlerinde kurum çalışanları yüksek stres ve baskı altında çalışırlar. $\mathrm{Bu}$ nedenle temkinli davranarak yeni hermeneutik problemler doğuracak mesaj ve eylemlerden kaçınmak gerekir. Özellikle kriz giderilene kadar yeni bir hermeneutik probleme yol açabilecek tüm tutumlardan uzak durmak oldukça önemlidir.

Hermeneutik probleme dayalı krizlere örnek olarak Onur Air firmasının Van depreminde yaşadığ 1 kriz önemlidir.

Onur Air Van'da yaşanan depremin ardından 25 Ekim 2011 günü www.facebook.com sitesindeki resmi sayfasında

"Dev bir aile olmamızı sağlayan 220 bin kişilik Facebook grubumuz adına hem Van'da yaşanan depremin felaketzedelerine hem de aziz şehitlerimizin bize emanet bıraktığı ailelerine olmak üzere her bir takipçimiz adına Onur Air olarak 0,5 liralık bedelle toplam 110 bin lira yardımı bugün yapıyoruz. Amacımız, şehit ailelerimiz ve depremzedelere yardım etmek isteyen sosyal medyanın duyarlı üyelerinin hassasiyetlerine aracılık etmek ve çok çabuk unutulan acılara dikkat çekmek. Şu andan itibaren kampanyamızı güçlendirmek adına www.facebook.com/onurair adresindeki kurumsal Facebook sayfamıza katacağınız her yeni takipçimiz için 0,5 TL’lik bir bağış daha yapacağız. Bugün yardım elini uzatma günü. Sizler, bu hassasiyete katılarak sadece duyarlılığını gösterecek kişileri bulun, biz de onlar adına bağışta bulunalım" ifadelerine yer vermiştir (BUSINESS ON AIR, 2018).

$\mathrm{Bu}$ ifadeler kamuoyu tarafindan Onur Air firmasının Van'da yaşanan acı olaylardan çıkar sağlamaya çalıştı̆̆ (burada çıkardan kasıt Onur Air firmasının www.facebook.com internet sitesi üzerindeki resmi sayfasının takipçi sayısını arttırma isteğidir) şeklinde yorumsanmıştır. "Onur Air kampanyayı şova döktü” ve "Onur Air'den "beş kuruşluk" 
kampanya!" şeklinde başlıklar atılmasına sebep olmuştur (SON SAYFA, 2018). Özellikle sosyal medya üzerinden hızla yayılan bir kriz haline dönüşmüştür. Kurum itibarını güçlendirmek ve sosyal sorumluluk iddiası ile yapılan bir çalışma hermeneutik problem nedeniyle büyük bir krize dönüşmüştür. Zira eylemin odağını oluşturan "her yeni takipçimiz için 0,5 TL'lik bir bağış daha yapacağız" ifadesi yorumsama için oldukça elverişli bir ifadedir.

Tepkiler üzerine firmanın yayınladığı düzeltme mesajı ise krizin büyümesine neden olmuştur. Firmanın düzeltme mesajı şu şekildedir:

"Amacı, şehitlerimizin ailelerine ve Van depremzedelerimize yapılacak yardımlara sosyal medyada dikkat çekmek olan kampanyamız bunu anlamayan bazı takipçilerimiz nedeniyle sona erdirilmiştir. Sizler adına gerçekleştirdiğimiz 110.000 TL'lik yardım makbuzlarımızın ilki ektedir, diğeri de gün içerisinde yayınlanacaktır. Sağduyu sahibi takipçilerimize iletmek isteriz ki sosyal medya dışında ayrıca nakdi bağış yapılması, bölgeye ücretsiz uçak tahsis edilmesi ve çalışanlarımızın toplu yardımları gibi diğer katkılarımız sürmektedir ve sürmeye devam edecektir. Yanlış anlamalar için, yanlış anlamayan takipçilerimizden özür dileriz" (Hürriyet Arşiv, 2014).

Hermeneutik problemi çözmesi gereken düzeltme mesajı problemi daha da büyütmüştür. Bu açıklama Koca Mehmed Ragıp Paşa'nın "Merd-i kıpti şecaatin arz ederken sirkatin söyler" sözlerini hatırlatan bir açılama olmuştur. Zira kampanyanın sona erdirildiğini bildiren cümlede "bunu anlamayan bazı takipçilerimiz" ifadesi kullanılmıştır ki bu ifade yorumsama açısından değerlendirildiğinde, firmanın takipçilerinin bir kısmını "anlama" konusunda diğerlerinden daha yeteneksiz gördüğü ve yorumsamayı yapanların "anlama" konusunda yeterli olmadıkları şeklinde yorumsanmaya oldukça açıktır. Ancak tekrar belirtmek gerekir ki anlama- yorumsama sübjektiftir. Ayrıca "Yanlış anlamalar için, yanlış anlamayan takipçilerimizden özür dileriz" ifadesi kolektif bellekte Onur Air firmasının Van'da yaşanan acı olaylardan çıkar sağlamaya çalıştığı şeklinde yorumsayan /anlayan kişilerden özür dilemediği, özrü sadece bu şekilde yorumsamayan kesimden dilediği şeklinde anlaşılmaktadır. Firma bir süre sonra "Yanlış anlamalar için, yanlış anlamayan takipçilerimizden özür dileriz" ifadesini "Yanlış anlamalar için özür dileriz" olarak değiştirmiş ancak "bunu anlamayan bazı takipçilerimiz" ifadesi değiştirilmemiştir. Bu örnekte de görüldüğü gibi kampanyayı ve kampanyanın mesajlarını tasarlayan Onur Air çalışanları ve kriz oluştuğu anda telafi mesajını yayınlayan Onur Air yetkilileri kamuoyunun ve kolektif belleğin ön-anlama sürecini ve yorumsama ihtimallerini bilmeden ve değerlendirmeden hareket etmişler ve sonuç olarak hermeneutik probleme dayalı bir krizle karşı karşıya kalmışlardır.

Hermeneutik mesajın kaynağının ruh halini idrak etmeyi de kapsayan bir alandır. Hermeneutik probleme dayalı krizlerde yorumsamanın bir hermeneutik probleme dönüşmesinin başlıca sebeplerinden biri de yorumsamayı yapanların mesajın kaynağının ruh haline ilişkin anlamlandırma süreçleridir.

\subsubsection{Hermeneutik Probleme Bă̆lı olmayan Kriz Döneminde Kriz Yönetimi ve Hermeneutik}

Hermeneutik bir problemin sebep olmadığ 1 bir kriz durumda yine en önemli faktörlerden biri stres, gerilim, belirsizlik ve bask1 altında olan kurumun mevcut krizin şiddetini arttıracak hermeneutik problemler meydana getirmemesidir. "Krizler örgütlerin algılama yeteneklerini bozmakta, örgütleri ortaya çıkan problem karşısında hiçbir şey yapmamaya ya da uygunsuz davranmaya yöneltmektedir" (Haşit, 2000: 10). BP örneğinde krizin temeli hermeneutik bir probleme dayanmamakla birlikte, kriz döneminde oluşan hermeneutik problemler krizin şiddetini arttırmıştır. 
BP'nin Yönetim Kurulu Başkanı Tony Hayward, BP krizinde yaptığı açıklama olan "Meksika Körfezi çok büyük bir okyanustur. Okyanusa salınan petrol ve çözücü madde toplam su hacmine göre çok az bir miktardır" (CBS NEWS, 2018) açıklaması çokanlamlı bir açıklamadır ve arzulanmayan bir şekilde yorumsamaya oldukça yatkın bir açıklamadır. Nitekim bu açıklama krizin şiddetini arttırmıştır. Tony Hayward bu açıklama ile muhtemelen "okyanusa salınan petrol ve çözücü maddenin okyanusa zarar verecek bir miktarda olmadığı"nı ifade etme amacı gütmekteydi. Ancak bu açıklama BP'nin “okyanusa verdiği zararı küçümsendiği” şeklinde yorumsanmıştır. Nitekim mesajın kendisi çokanlamlıdır ve bu şekilde bir yorumsamaya açıktır. Ancak bu yorumsamamın tek sebebinin salt bu mesaj ile ilgili olduğunu düşünmek yanlış olacaktır. Zira bu yorumsamanın kolektif bellekteki ön-anlamında muhtemelen BP'nin krizde yaşanan ölümler ile ilgili daha önceki tavrı vb. gibi durumlar da vardir.

Görüldügü gibi bu krizde krizin temeli hermeneutik bir problem değildir. Ancak hermeneutik boyutları vardır. Kuruma ciddi etkileri olan, toplumun her kesimini ilgilendirebilen krizlerde buna ilaveten hermeneutik problemler yaşamak krizin şiddetini arttırmaktadır. Bu tür hermeneutik problemlere neden olan ana etkenler genellikle kriz anında hızlı hareket etme gerekliliği nedeniyle yeterince düşünülmeden yapılan açıklamalar ve krizin sebep olduğu stres ve baskı nedeniyle yapılan bazı tutarsız eylemler olarak siralanabilir. $\mathrm{Bu}$ eylemler kurum tarafından alınan ve uygulanan kararlara dayalı eylemler olabileceği gibi, üst düzey yöneticilerin hal ve hareketleri de hermeneutik problemler doğurabilmektedir.

2008 yılında Rusya ve Gürcistan arasında yaşanan krizde Gürcistan Devlet Başkanı Mihail Saakaşvili'nin katılacağı canlı televizyon yayını öncesi cep telefonuyla konuşurken kravatını çiğnediği görüntülendi. Bu görüntüler basında "Saakaşvili, kravatını yedi!" (Yeni Şafak, 2018) başlıkları ile yer aldı. Ayrıca Ukrayna'nın muhalif Bölgeler Partisi Saakaşvili'ye 365 adet kravat göndermiş ve yılın her günü çiğnemesi için 365 adet kravat yolladıklarını bildirmiş̧ir (Sol Haber, 2018). Rusya Başbakanı Vladimir Putin, Mihail Saakaşvili'nin davetli olarak Ukrayna'ya gitmesi üzerine alaycı bir şekilde "Bizim meslektaşlarımızın (Ukrayna ve Gürcistan liderleri) ne yaptıklarıyla ilgili hiçbir fikrim yok. Ama Ukrayna Cumhurbaşkanı Yuşçenko'ya, Gürcü meslektaşıyla akşam yemeğine hazırlanırken kravat takmamasını tavsiye ediyorum" (Haber Vaktim, 2018) demiştir.

$\mathrm{Bu}$ olay dünya kamuoyunda bir "korku" ve "aşırı stres" durumu olarak yorumsanmıştır. Daha da derin yorumsama Gürcistan Devlet Başkanı'nın dolayısıyla Gürcistan'ın Rusya'dan yüksek düzeyde korktuğu ve Rusya karşısında oldukça zayıf olduğu yorumsamasıdır. Bu yorumsama "doğru" veya "yanlış" olabilir. Ancak Gürcistan tarafindan "arzu edilmeyen" bir yorumsama olduğu kesindir. Yorumsamayı yapanların tamamı şüphesiz beden dili uzmanı değildir. Ayrıca bu harekete neden olan gerçek olgunun ne olduğunu belirlemek için beden dili uzmanı olmak da yetersizdir. Zira Saakaşvili'nin bir dizi olaya ne şekilde tepki verdiği, bunların nedenleri ve kravatını çiğnediği an tam olarak aklından ne geçtiğini bilmek gerekir ki bu imkansızdır. Ancak yorumsamayı yapanlar hermeneutiğin doğası gereği bir dizi ön-anlam olgusuyla hareketin sahibi olan Saakaşvili’yi kendisinden daha iyi anlama iddiasında bulunularak yapmıştır.

$\mathrm{Bu}$ örnekte de görüldüğü gibi kriz hermeneutik kaynaklı olmamasına rağmen hermeneutik problem, itibar kaybına ve krizin büyümesine neden olmuştur ve telafisi imkansız denilebilecek kadar zordur. Nitekim olay ile ilgili yapılan açıklamaların ve verilen cevapların hiçbiri kamuoyunun dikkatini çekememiştir. Saakaşvili'nin süreç ile ilgili canlı yayında yaptığı açıklamalar dahi basında çok az yer almasına rağmen, kravat çiğneme görüntüleri defaatle dünya basınında ve sosyal medyada yer almıştır. 
Yaşanan hermeneutik sorunlar nedeniyle krizde kuruma destek veren bazı diğer unsurların da bu desteği çekmesi/çekmek zorunda kalması muhtemeldir. Nitekim destek veren unsurlar hermeneutik problemler ile oluşan olumsuz algıdan etkilenmek istemezler.

\subsubsection{Kriz Yönetiminde Kriz Sonrası Dönem ve Hermeneutik}

Kriz sonrası dönemde kriz yönetimi açısından değerlendirmeler yapılmakta, krize kaynaklık eden olaylar tespit edilerek giderilmekte, alınan zarar hesaplanmakta, önceki dönemlerde uygulanan tekniklerde gerekli değişiklikler yapılmaktadır.

Hermeneutik açıdan bu uygulamalara paralel olarak krize neden olan veya krizin şiddetini arttıran hermeneutik problemler incelenmelidir. Yorumsama sorunlarını gidermek için kriz sonrası dönemde yapılması gereken önemli unsurlardan biri kriz neticesinde kolektif ön-anlama olgusunda bir değişikliğin olup olmadığının incelenmesidir. Eğer kriz ön-anlama sürecinde ciddi değişiklikler meydana getirmiş ise, ilerleyen dönemlerde hermeneutik problemler ile karşılaşmamak için bu değişiklikler dikkate alınarak hareket edilmelidir. Ayrıca kriz yönetimi dairesel bir döngü olduğu için kriz sonrası dönem kriz öncesi dönem uygulamalarının tamamını kapsamalıdır. Kriz öncesi ve kriz sonrası dönemde yorumsama dikkate alınarak hazırlanacak tüm materyaller muhtemel bir krizi önleyebileceği gibi algı oluşturma açısından oldukça önemli olduğu için "krizi fırsata çevirme" imkanı sunacaktır.

Asıl husus yine teolojik hermeneutikteki paradoksa dayanmaktadır. Hristiyan geleneğinde "anlaşılamayan", "anlaşılması güç" Tanrısal metinleri (ki bu metinler "yanlış" anlaşılmalardan ve anlaşılamamadan ötürü kriz doğurabilen metinlerdir) hermenutik ile anlaşılabilir kılınmaya çalışılmıştır. Oysa muhtemelen metinleri anlaşılmaz hale getiren yine yorumsamadır. Zira tüm İslami kaynaklara göre Kur'an-1 Kerim dışındaki semavi kitaplar insanlar tarafindan tahrif edilmiştir. Yani orijinal olması gereken metinler yorumsamalar ile doludur.

Buradan yola çıarak denilebilir ki anlaşılması gayet kolay ve doğal bir olgu hermeneutik problem nedeniyle "anlaşılmaz" yani kabul edilemez hale gelebilerek krizlere neden olabilmekte ve anlaşılması güç ve krize neden olabilecek bir olgu ise hermeneutik imkanların bilinmesiyle "anlaşılabilir" yani kabul edilebilir bir hale getirilebilmektedir. İşte bu nedenle hermeneutiğin derinlemesine irdelenmesi krizi firsata çevirme açısından oldukça önemlidir.

\section{Sonuç}

Literatürde daha önce yapılmış kriz yönetimi ve hermeneutik ilişkisine vurgu yapan bir çalışma olmamakla birlikte modern hermeneutiğin iletişimin tüm alanlarını da kapsaması gerektiğini söylemek mümkündür. Zira etkin bir iletişim için hermeneutik bilgisine sahip olmak, hermeneutik imkanlardan yararlanmak ve bu doğrultuda hareket etmek; alg1 konusunu idrak edebilmek, yönlendirebilmek ve uyumlu davranabilmek için faydalı olacaktır.

Günümüz, global bir dünyanın aktörleri sessiz çağın sesi olan kurumların şirketlerin ve kampanyaların kıyasıya yarıştığı halkla ilişkiler savaşlarıyla etkinliklerini gerçekleştirmeye çalıştı̆̆ bir dönem olarak nitelendirilmektedir. Kurumsal yapılanmaların halkla ilişkiler ile can bulduğu ve hedef kitle nezdinde halkla ilişkiler faaliyetleri ile kendini gerçekleştirdiği bir dönemi yaşantılarken, kurumsal yapılanmalar bünyesinde ya da organizasyon etkinlik alanı dahilinde meydana gelen krizler, kurumların hedeflerinden sapmasına, marka değerinin düşmesine, ciddi bir imaj kaybı yaşamasına sebep olacaktır. Devletler de dahil olmak üzere, kurumların yaşadığ 1 krizlerin temelindeki hermeneutik problem, yoruma dayalı algının 
yönetiminin başarılı bir şekilde gerçekleştirilmesini kaçınılmaz bir zorunluluk haline getirecektir.

Kriz yönetiminin iletişim boyutunun temelinde yatan hermeneutik tutarl1lık ve strateji, krizlerin yönetimsel anlamda başarılı olması krizin proaktif olarak avantaja dönüştürülmesinin vazgeçilmez bir unsuru olarak karşımıza çıkmaktadır. Mesajların gayet yalın ve açık seçilememesi, süslü ya da üstü kapalı anlatımların, savunucu üslupların benimsenmesi, temel iletişim stratejilerinin ve iletişim taktiklerinin dişında kendiliğinden veya reaksiyona dayalı irrasyonel ifadelerin, baskınlaşmış akılın egemenliğinde deklare edilmesi, yanlı ve gerçekliği yadsıyan açıklamaların sosyal infial yaratacak üsluplarla açıklanması, açıklanan ve anlatılmak istenen gerçekliğin hedef kitle nezdinde dönüşmesine ve algısal sorunların doğmasına neden olmaktadır. Kolektif bellekte dönüşen mesajların arzu edilmeyen bir şekilde kodlanması temel hermeneutik açıdan kriz yönetiminin stratejik bir unsuru olarak görülmektedir.

Özetle hermeneutik problemler krizlere neden olabilmekte veya krizin şiddetini arttırabilmektedir. Hermeneutik bilgisine sahip olmak halkla ilişkilerde kriz yönetimi açısından faydalar sağlayacaktır.

\section{Kaynakça}

Akdağ, M. (2005). "Halkla İlişkiler ve Kriz Yönetimi”, Selçuk Üniversitesi Sosyal Bilimler Enstitüsü Dergisi, 14:1-20.

Aktaş, S. (2011). "Hukukta Yorum Çabaları”, Erzincan Üniversitesi Hukuk Fakültesi Dergisi, C. $X V, 3-4: 1-33$.

Alan, B. (2008). Bir Felsefi Yöntem Olarak Hermeneutik, Muğla Üniversitesi Sosyal Bilimler Enstitüsü, Basılmamış Yüksek Lisans Tezi, Muğla.

Alioğlu, N. (2007). "Hermeneutik Açıdan Anlam Üretme ve Örnek Görüntüsel Gösterge Çözümlemesi”, VIII. Uluslararası Görsel Göstergebilim Kongresi, T.C. İstanbul Kültür Üniversitesi, İstanbul, 2: 1191-1203.

Arvasi, A. (2009). Kendini Arayan İnsan, İstanbul: Bilgeoğuz Yayınları.

Ataman, I. (2007). Bir Yorumlama Yöntemi Olarak Hermeneutik: Erol Akyavaş Üzerine Inceleme, Anadolu Üniversitesi Sosyal Bilimler Enstitüsü, Sanat Bilimi Anabilim Dalı, Yüksek Lisans Tezi, Eskişehir.

Augustine, Normon R. (2000), “Önlemeye Çalıştı̆̆ımız Krizi Yönetmek”, İçinde: Harward Business Review Kriz Yönetimi (Çev: S. Atay), İstanbul: Mess Yayınları.

Aytül Kasapoğlu, M. (1992). “Sosyolojide Hermeneutik Uygulamaları”, Felsefe Dünyası Dergisi, 5:59-70.

Bernstein Richard, J. (1986). From Hermeneutics to Praxis, Hermeneutics and Modern Philosophy, Albany: State University of New York Press.

Bernstein Richard, J. (2011). Beyond Objectivism and Relativism: Science, Hermeneutics, and Praxis, Pennsylvania: University of Pennsylvania Press.

Bilen, O. (2001). Çağdaş Yorumbilim Kuramları, Ankara: Kitabiyat Yayınları.

Bollnow, O. F. (1995). “İfade ve Anlama”, Hermeneutik Üzerine Yazılar, 93-139.

BP Oil Spill Crisis Management: How Not to Do it, http://www.cbsnews.com/news/bp-oilspill-crisis-management-how-not-to-do-it/ (Erişim: 15.06.2018). 
Büyükçanga, M. (2008). “Türk Mimarisinde Sekiz Köşeli Yıldız Motifleri”, 6. Uluslararası Türk Dünyas1 Sosyal Bilimler Kongresinde Bildiri, Celalabat, 1230 - 1234.

Cevizci, A. (1999). Felsefe Sözlüğü, İstanbul: Paradigma Yayınları.

Dartma, B., Demirci, M., Ünver, M. ve diğer. (2013). Tefsir Tarihi ve Usulü, Eskişehir: T.C. Anadolu Üniversitesi Açıöğretim Fakültesi Yayını.

Dellaloğlu, B. (1998). Toplumsalın Yeniden Yapılanması: Habermas Üzerine bir İnceleme, İstanbul: Bağlam Yayınları.

Demir, Ş. (2013). “Ölüme Bağlı Tasarrufların Yorumu”, Türkiye Adalet Akademisi Dergisi, 14:1151-1173.

Dilthey, W. (1996). "The Rise of Hermeneutics", In: Selected Works-Volume IV: Hermeneutics and the Study of History, New Jersey: Princeton University Press, 229-244.

Dilthey, W. (1999). Hermeneutik ve Tin Bilimleri, (Çev: D. Özlem), İstanbul: Paradigma Yayınlar1.

Doğan, Ö. (2006). Anlamdan Geleneğe, Kimlikten Özgürlüğe (Kavramlar ve Tarihleri II), İstanbul: İnk1lap Kitabevi.

Erhat, A. (1989). Mitoloji Sözlüğ̈̈, İstanbul: Remzi Kitabevi.

Gadamer, H. G. (2002). Kuşkucu Hermeneutik, Hermeneutik ve Hümaniter Disiplinler, (Çev: H. Arslan), İstanbul: Paradigma Yayınları.

Gadamer, H. G. (2003). Hermeneutik Üzerine Yazılar, (Çev: D. Özlem), İstanbul: İnkilap Kitabevi.

Gadamer, H. G. (2007). The Gadamer Reader: A Bouquet of the Later Writing, (Trans: R. E. Palmer), Evanston: Northwestern University Press.

Gadamer, H. G. (2008). Hakikat ve Yöntem (I. Cilt), (Çev: H. Arslan ve İ. Yavuzcan), İstanbul: Paradigma Yayınları.

Gadamer, H. G. (2009). Hakikat ve Yöntem (II. Cilt), (Çev: H. Arslan ve İ. Yavuzcan), İstanbul: Paradigma Yayınları.

Geltsetzer, L. (1997). "Hermeneutik”, (Çev: Z. Uludağ), Ondokuzmayıs Üniversitesi Eğitim Fakültesi Dergisi, 10:95-101.

Göka, E. (1993). “Hermenötik Üzerine”, Türkiye Günlüğ̈̈ Dergisi, 22:84-94.

Haşit, G. (2000). İşletmelerde Kriz Yönetimi ve Türkiye’nin Büyük Sanayi İ̧sletmeleri Üzerinde Yapılan Araştırma Çalışması, Eskişehir: Anadolu Üniversitesi Yayınları.

Hekman, S. (2012). Bilgi Sosyolojisi ve Hermeneutik, (Çev: H. Arslan-B. Balkız), İstanbul: Paradigma Yayınları.

Howard Roy, J. (1982). Three faces of hermeneutics: An introduction to current theories of understanding, California: University of California Pr.

Hürriyet, http://hurarsiv.hurriyet.com.tr/goster/haber.aspx?id=19093160\&yazarid=350 (Erişim: 01.02.2014).

İbn Hacer, Ahmed b. Ali el- Askalani. (1990). Fethu'l Bari bi Şerhi Sahihi'l Buhari, Beyrut: Daru'l Marife.

İnalcık, H. (2002). "Hermenötik, Oryantalizm, Türkoloji”, Doğu Batı Dergisi, 20:13-39. 
Kılıç, M. (2005). Hukuksal ve Teolojik Metinleri Anlama Sorunu: Felsefi Hermenötik Bağlaminda Bir Analiz, İstanbul: İstanbul Barosu Yayınları.

Kurt M. V. (1994). The Hermeneutic Reader, (ed. Kurt Mueller-Vollmer), New York, The Continuum Company.

Luecke, R. (2009). Kriz Yönetimi Felaketleri Önleme Becerinizi Geliştirin, (Çev: Ö. Sarıkaya) İstanbul: Türkiye İş Bankası Kültür Yayınları.

Onur Air Kampanyayı Şova Döktü, http://www.sonsayfa.com/Haberler/Ekonomi/Onur-Airkampanyayi-sova-doktu-208792.html (Erişim: 01.02.2018).

Onur Air-Sosyal Sorumluluk Kampanyas1, http://www.businessonair.net/2011/10/onur-airsosyal-sorumluluk-kampanyas.html (Erişim: 29.06.2018)

Ormitson, G. L. ve Schrift, A. D. (2002). Hermeneutiğe Giriş, Hermeneutik ve Hümaniter Disiplinler (Çev: H. Arslan), İstanbul: Paradigma Yayınları.

Örnek, A. Ş. ve Aydın Ş. (2007). Kriz ve Stres Yönetimi, Ankara: Detay Yayıncılık.

Özcan, Z. (2000). Teolojik Hermenötik, İstanbul: Alfa Yayınları.

Öztürk, E. (2009). “Hermeneutiğin Tarihsel Dönüşümü”, Journal of World of Turks/Zeitschrift für die Welt der Türken, 1:2: 145-175.

Özür Kabahatten Büyük Olursa, http://www.dunya.com/ozur-kabahatten-buyuk-olursa179748h.htm (Erişim: 05.05.2018).

Palmer, R. E. (1969). Hermeneutics: Interpretation Theory in Schleiermacher, Evanston: Northwestern University Press.

Petrot H. J. (1981). Meaning and Understanding, Bouveresse(ed), Berlin, Walter de Gruyter.

Pira, A. ve Sohodol Ç. (2012). Kriz Yönetimi Halkla İlişkiler Açısından Bir Değerlendirme, İstanbul: İletişim Yayınları.

Richard E. P. (1969). Hermeneutics: Interpretation Theory in Schleiermacher, Dilthey, Heidegger, and Gadamer, Evanston, Northwestern University Press.

Ricoeur, P. (2009). Yorumların Çatışması / Hermenoytik Üzerine Denemeler I, (Çev: H. Arslan), İstanbul: Paradigma Yayınc1lik.

Saakaşvili ile Yemek Yerken Kravat Takma, http://www.habervaktim.com/haber/95018/saakasvili-ile-yemek-yerken-kravattakma.html (Erişim: 01.06.2018).

Saakaşvili’ye Çiğnemesi için Hediye Kravat!, http://haber.sol.org.tr/dunyadan/saakasvili-yecignemesi-icin-hediye-kravat-haberi-5046 (Erişim: 07.06.2018).

Sansasyon Yoksa Haber de Yok, http://www.hurriyet.com.tr/yazarlar/24559961.asp (Erişim: 04.02.2018).

Saygın, T. (2008). Aşırı Yorum Sorunu ve Grünberg'de Anlamın Sınırları, ODTÜ Felsefe Bölümü 25. Yıl Etkinlikleri Anlam Kongresi, Sözlü Bildiri, Ankara.

Saygın, T. (2009). "Sosyal Bilimlerin Doğası ve Hermeneutik", VI. Ulusal Sosyoloji Kongresi Bildiri Kitabı, Toplumsal Dönüşümler ve Sosyolojik Yaklaşımlar, Adnan Menderes Üniversitesi, Aydın, 101-111.

Şimşek Narbay, M. (2006). Kriz İletişimi, Ankara: Nobel Yayın Dağıtım. 
Taşdelen, V. (2008). Hermeneutiğin Evrimi -Kesitler, Ankara: Hece Yayınları.

Tatar, B. (1999). Felsefì Hermenötik ve Yazarın Niyeti, İstanbul: Vadi Yayınları.

Tatar, B. (2004). Hermenötik, İstanbul: İnsan Yayınları.

Toprak, M. (2003). Hermeneutik (Yorumbilgisi) ve Edebiyat, İstanbul: Bulut Yayınlar1.

Vesek, S. (2004). Doğan Özlem'de Hermeneutik, Cumhuriyet Üniversitesi Sosyal Bilimler Enstitüsü, Yüksek Lisans Tezi, Sivas.

Weber, M. (1995). Toplumsal ve Ekonomik Örgütlenme Kuramı, (Çev: Ö. Ozankaya), Ankara: İmge Kitabevi.

West, D. (2005). Kıta Avrupası Felsefesine Giriş, (Çev: A. Cevizci), İstanbul: Paradigma Yayınlar1.

Yenişafak, http://www.yenisafak.com.tr/dunya/?t=18.08.2008\&i=135318 (Erişim: 01.02.2014). 